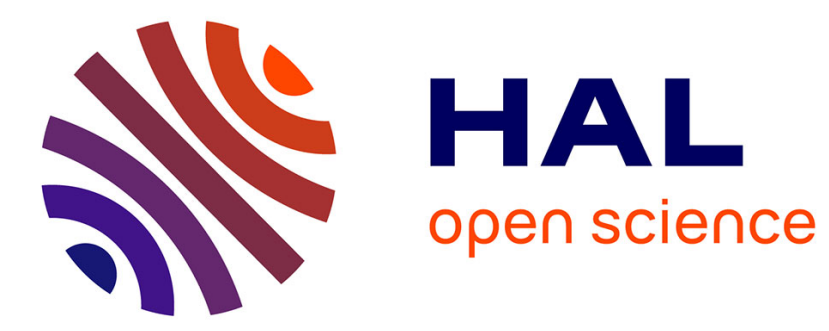

\title{
The Kufrah paleodrainage system in Libya: A past connection to the Mediterranean Sea?
}

Philippe Paillou, Stephen Tooth, S. Lopez

\section{To cite this version:}

Philippe Paillou, Stephen Tooth, S. Lopez. The Kufrah paleodrainage system in Libya: A past connection to the Mediterranean Sea?. Comptes Rendus Géoscience, 2012, 344 (8), pp.406-414. 10.1016/j.crte.2012.07.002 . hal-00833333

\section{HAL Id: hal-00833333 https://hal.science/hal-00833333}

Submitted on 12 Jun 2013

HAL is a multi-disciplinary open access archive for the deposit and dissemination of scientific research documents, whether they are published or not. The documents may come from teaching and research institutions in France or abroad, or from public or private research centers.
L'archive ouverte pluridisciplinaire HAL, est destinée au dépôt et à la diffusion de documents scientifiques de niveau recherche, publiés ou non, émanant des établissements d'enseignement et de recherche français ou étrangers, des laboratoires publics ou privés. 
The Kufrah Paleodrainage System in Libya:

A Past Connection to the Mediterranean Sea ?

\title{
Le système paléo-hydrographique de Kufrah en Libye :
}

\author{
Une ancienne connexion avec la mer Méditerranée ?
}

\author{
Philippe PAILLOU \\ Univ. Bordeaux, LAB,UMR 5804, F-33270, Floirac, France \\ Tel: +33557776126 Fax: +33557776110 \\ E-mail: philippe.paillou@obs.u-bordeaux1.fr
}

\begin{abstract}
Stephen TOOTH
Institute of Geography and Earth Sciences, Aberystwyth University, Ceredigion, UK
\end{abstract}

Sylvia LOPEZ

Univ. Bordeaux, LAB,UMR 5804, F-33270, Floirac, France 
Abstract: Paillou et al. (2009) mapped a 900 km-long paleodrainage system in eastern Libya, the Kufrah River, that could have linked the southern Kufrah Basin to the Mediterranean coast through the Sirt Basin, possibly as long ago as the middle Miocene. We study here the potential connection between the terminal part of the Kufrah River and the Mediterranean Sea through the Wadi Sahabi paleochannel, which may have constituted the northern extension of the lower Kufrah River paleodrainage system. New analysis of SRTM-derived topography combined with Synthetic Aperture Radar images from the Japanese PALSAR orbital sensor allowed the mapping of seven main paleochannels located west of the Kufrah River, each of which is likely to have formed a tributary that supplied water and sediment to the main paleodrainage system. The northernmost four paleochannels probably originated from the Al Haruj relief, a Pliocene alkaline basaltic intra-continental volcanic field, and potentially connected to the Wadi Sahabi paleochannel. The remaining three paleochannels are in the more southerly location of the Sarir Calanscio, northeast of the Tibesti mountains, and barely present a topographic signature in SRTM data. They end in the dunes of the Calanscio Sand Sea, forming alluvial fans. The most southern paleochannel, known as Wadi Behar Belama, was previously mapped by Pachur et al. (1996) using LANDSAT-TM images, and was interpreted by Osborne et al. (2008) as representing part of an uninterrupted sediment pathway from the Tibesti mountains to the Mediterranean Sea. Processing of SRTM topographic data revealed local depressions which allow to connect the seven paleochannels and possibly the terminal alluvial fan of the Kufrah River to the Wadi Sahabi paleochannel, through a $400 \mathrm{~km}$-long, south-north oriented, paleocorridor. These new findings support our previous hypothesis that proposed a connection between the lower Kufrah River in the region of the Sarir Dalmah and the Wadi Sahabi paleochannel, which connected to the Mediterranean Sea. Including the newly mapped paleochannels, the Kufrah River paleowatershed, at its maximum extent, would have covered more than $400000 \mathrm{~km}^{2}$, representing close to a quarter of the surface area of Libya.

Keywords: Kufrah River, paleodrainage system, Wadi Sahabi, Libya, PALSAR, SRTM. 
Résumé : Paillou et al. (2009) ont cartographié un ancien réseau hydrographique de 900 km de long en Libye orientale, la rivière de Kufrah, qui a potentiellement relié le basin de Kufrah

à la mer Méditerranée au Miocène. Nous étudions ici la possible connexion entre la partie terminale de la rivière de Kufrah et la mer Méditerranée, via le paléochenal Wadi Sahabi, qui a potentiellement joué le rôle de partie terminale du système hydrographique de Kufrah. L'analyse de données topographiques SRTM, combinées à des images radar issues du capteur orbital japonais PALSAR, a permis de cartographier sept paléochenaux principaux à l'ouest de la rivière de Kufrah, chacun ayant potentiellement joué le rôle d'affluent pour le réseau hydrographique principal. Les quatre paléochenaux les plus au nord sont probablement originaires des reliefs du Al Haruj, un champ volcanique basaltique intra-continental du Pliocène, et se connectent au paléochenal Wadi Sahabi. Les trois paléochenaux les plus au sud sont situés dans le Sarir Calanscio, au nord-est du Tibesti, et présentent une signature topographique difficilement détectable dans les données SRTM. Ils se terminent dans les dunes de la mer de sable de Calanscio, formant des cônes alluviaux. Le paléochenal le plus méridional, connu sous le nom de Wadi Behar Belama, a été précédemment cartographié par Pachur et al. (1996) à partir d'images LANDSAT-TM. Il a été considéré par Osborne et al. (2008) comme le segment d'un couloir sédimentaire continu qui reliait les montagnes du Tibesti à la mer Méditerranée. Le traitement des données topographiques SRTM a permis de mettre en évidence des dépressions locales qui permettent de relier les sept paléochenaux, et potentiellement le cône alluvial terminal de la rivière de Kufrah, au paléochenal Wadi Sahabi, et ce via un paléocorridor de $400 \mathrm{~km}$ de long, orienté sud-nord. Ces résultats confortent notre hypothèse d'une connexion entre la partie terminale de la rivière de Kufrah dans le Sarir Dalmah et la mer Méditerranée, via le paléochenal Wadi Sahabi. En tenant compte des sept nouveaux paléochenaux cartographiés, le bassin versant de la rivière de Kufrah aurait couvert plus de $400000 \mathrm{~km}^{2}$, représentant presque un quart de la surface actuelle de la Libye.

Mots clés : Rivière de Kufrah, paléo-hydrographie, Wadi Sahabi, Libye, PALSAR, SRTM. 


\section{Introduction}

While the central Sahara is now hyper-arid, extensive paleodrainage systems originating in

the Tibesti mountains used to flow northward to the Mediterranean Sea and southward to the Chad Basin during wetter periods (Petit-Maire, 1998; Maley, 2010). Evidence of such paleodrainage systems have been detected using various remote sensing imagery (Griffin, 2006; Pachur and Altmann, 2006; Drake et al., 2008), particularly by orbital imaging radar, which allows the detection of paleochannels even when masked by Quaternary aeolian deposits (McCauley et al.,1982; Abdelsalam and Stern, 1996; Robinson et al., 2006; Paillou et al., 2010). Griffin (2002) proposed a vast paleodrainage system, the "Sahabi River system" (see Figure 1), which would have flowed from the Messinian (late Miocene) Lake Chad, eroded the east Tibesti valley, and have ended in a well preserved channel near the coast of the Gulf of Sirt, the Wadi Sahabi paleochannel (Barr and Walker, 1973; Hallet, 2002; Swezey, 2009). The proposed path for the Sahabi River is poorly defined, however, and is based mainly on the interpretation of low resolution topographic maps and on hypothetical fragments of river channels detected in LANDSAT-TM images (Griffin, 2006; Griffin 2011). Drake et al. (2008) also proposed that the Gulf of Sirt was fed by large river systems, originating in northern and eastern Tibesti, through deep canyons that drained much of Libya during the late Miocene. Although it was not mapped precisely, Drake et al. (2008) supported the idea of the Sahabi River system that connected northern Chad and southeast Libya to the Mediterranean Sea during humid periods in the Messinian. They also proposed the hypothesis that this paleodrainage system was later captured by a more easterly one, the "River Al Kufrah", which was activated by tectonic subsidence in the Kufrah Basin during the Pliocene, and linked to the Mediterranean Sea through the Wadi Sahabi paleochannel in the Sirt Basin. The geographical mapping of this Kufrah River was initiated by Robinson et al. (2006) and completed by Paillou et al. (2009) (see Figure 1). Ghoneim et al. (2012) confirmed the geographical extent of the Kufrah River and proposed that its southwestern branch may have served as an outlet from the Megalake Chad to the Mediterranean Sea during humid phases of the Neogene. However, the hypothesis of a Sahabi River and/or Kufrah River system that 
would provide a path for the Megalake Chad to discharge into the Mediterranean Sea is still a matter of debate since there is yet no clear evidence of a connection between the Chad and

Kufrah basins, and other authors propose an evacuation of the overflow waters to the southern Niger (Maley, 2004; Leblanc et al., 2006; Schuster et al., 2009; Maley, 2010). The results we present in this study are not to be interpreted as supporting nor refuting the hypothesis of a continuous connection between the Chad basin and the Mediterranean Sea, since we rather focus here on the relationships between the lower Kufrah River and northern Tibesti and Al Haruj reliefs, and propose possible connections to the Mediterranean Sea based on the mapping of actual paleochannels and on the analysis of topography. In a same quantitative mapping approach, Pachur and colleagues have also proposed and partially mapped an extensive paleodrainage system that could have connected the Tibesti mountains to the Sirt Basin during the Holocene (Pachur, 1980; Pachur, 1996; Pachur and Hoelzmann, 2000). This paleodrainage system was divided into two main parts: One western part that was sourced in the northern Tibesti mountains and then flowed to the north through the Behar Belama paleochannel, and an eastern part that possibly originated in the eastern Tibesti mountains, flowed into the Kufrah Basin, followed the present-day Wadi Blittah and ended as an inland delta in the Sarir Dalmah during the Holocene (Pachur, 1996; Pachur and Altmann, 2006).

We present here the mapping of possible new tributaries of the Kufrah River, with their potential flow path to the Mediterranean Sea, and discuss the implications for establishing an extension of the watershed of this major Libyan paleodrainage system. Our results confirm the previous work by Pachur and colleagues and we propose in addition some potential water flow paths to the terminal Wadi Sahabi paleochannel. Although we have no new geochronological or geochemical data, if it can be determined that these tributaries were active at intervals during the late Pleistocene, then our findings would lend strong support to the previous hypothesis of Rohling et al. (2002) and Osborne et al. (2008), who have proposed a continuous "humid corridor" between southeastern Libya and the Mediterranean Sea at around 120 ka. 


\section{Mapping of the Kufrah River using Orbital Imaging Radar}

Using data from the PALSAR L-band orbital radar of the Japanese ALOS satellite

(Rosenqvist et al., 2007), we are conducting continental-scale mapping of several arid regions on Earth, with an initial objective to evaluate potentials of low frequency radar for planetary exploration (Paillou et al., 2006). A mosaic of the whole Sahara has been built from PALSAR strips, allowing an efficient detection of sub-surface geological features, particularly craters and paleodrainage networks (Paillou et al. 2003; Paillou et al. 2004; Paillou et al., 2006; Paillou et al., 2009; Paillou et al., 2010), because radar can probe through the first few meters of superficial eolian deposits (McCauley et al., 1982; Schaber et al., 1986; Paillou et al., 2003; Baghdadi et al., 2005; Grandjean et al., 2006). We thus precisely mapped a $900 \mathrm{~km}$-long paleodrainage system in eastern Libya, termed the Kufrah River (see Figure 1), which could have linked the Kufrah Basin to the Mediterranean coast through Wadi Sahabi paleochannel in the Sirt Basin, possibly as far back as the middle Miocene (Paillou et al., 2009). The headwaters of this paleodrainage system are mainly in southern Libya, with detected tributaries arising in three main areas: El Fayoud and El Akdamin hamadas in northeastern Tibesti, northern Uweinat close to the Sudanese border, and the western Gilf Kebir and Abu Ras plateaux on the Egyptian border (see Figure 1). The Tibesti and Uweinat tributaries, more than $350 \mathrm{~km}$-long, flowed in wide paleovalleys which join in the present-day Kufrah oasis. These paleovalleys had previously been detected by Robinson et al. (2006) using RADARSAT-1 Cband orbital radar. About $80 \mathrm{~km}$ north-east of the Kufrah oasis, a shorter (200 km-long) tributary joins from the Gilf Kebir and Abu Ras plateaux. From the Kufrah oasis, the main paleochannel becomes narrower (less than $1 \mathrm{~km}$ ) and clearly incises the sandstone bedrock. It follows the present-day Wadi Blittah to the northern Jebel Dalmah over a distance of about 230 km. Farther north, in the Sarir Dalmah, the Kufrah River then disperses as a network of small, shallow paleochannels across the surface of a broad alluvial fan that covers more than 15000 $\mathrm{km}^{2}$ (see Figure 1). It is not possible to follow the paleodrainage course to the north, because the large sand dunes of the Calanscio Sand Sea preclude radar mapping of the sub-surface. However, about $300 \mathrm{~km}$ away to the north-west and emerging from beneath the Calanscio 
Sand Sea, lies the major, 2 to $4 \mathrm{~km}$-wide, alluvium-filled Wadi Sahabi paleochannel that incised more than 300 meters into Miocene carbonate strata (Barr and Walker, 1973). In a

previous study (Paillou et al., 2009), we proposed that the sand sea could hide an ancient pathway between the Sarir Dalmah alluvial fan and the Wadi Sahabi paleochannel (cf. "north path" marked by the red dotted line in Figure 1).

\section{New Tributaries from PALSAR and SRTM Data}

In addition to our PALSAR mosaic of the Sahara, we have used topographic information derived from SRTM data. The Shuttle Radar Topography Mission consisted of an interferometric radar system that flew on-board the Space Shuttle Endeavour during an 11-day mission in February 2000 (Farr et al., 2007). It produced a high-quality global Digital Elevation Model at a resolution of 3 arc-second (about $90 \mathrm{~m}$ ), covering all land between latitudes $56^{\circ} \mathrm{S}$ and $60^{\circ} \mathrm{N}$. SRTM data are organized in $1^{\circ} \times 1^{\circ}$ cells, and have an absolute vertical height accuracy better than 15 meters. The HydroSHEDS (Hydrological data based on SHuttle Elevation Derivatives at multiple Scales) data set was computed from SRTM topography data by the USGS, and provides hydrographic information such as river networks, watershed boundaries and drainage directions (Lehner et al., 2008). Due to errors and voids in SRTM data, river network products are susceptible to various errors, particularly in very low relief regions. This is unfortunately the case in our region of interest, where low relief combines with numerous voids in SRTM coverage (mainly due to the radar wave penetration and attenuation in sand dunes), and so does not enable the reliable generation of river networks in HydroSHEDS. However, the computing of watershed boundaries is less sensitive to such problems, and watershed boundaries available in HydroSHEDS data can be useful for predicting areas to prospect for paleochannels using radar imagery. In particular, it appears that a large drainage basin exists west of the lower Kufrah River, arising in the Sarir Tibesti and flowing north in the Sarir Calanscio (see Figure 1): A paleodrainage contribution from the western topography (Al Haruj area and northern Tibesti mountains) should then be expected. 
Combining topography derived from the SRTM data and the sub-surface imaging capabilities of the PALSAR sensor, we mapped seven new paleochannels that are likely to

have contributed water and sediment to the Kufrah River paleodrainage system from the west (see Figure 2). The northernmost four paleochannels probably originated from the Al Haruj relief, a Pliocene basaltic intra-continental volcanic field, and potentially connected to the northern Wadi Sahabi paleochannel. The remaining three paleochannels, which include the Wadi Behar Belama paleochannel previously mapped by Pachur and Altmann (2006), are found in the more southerly region of the Sarir Calanscio, located northeast of the Tibesti mountains. They end in the Calanscio Sand Sea, forming alluvial fans that are oriented and slope in the direction of the hypothesized but as yet unmapped $300 \mathrm{~km}$-long "north path" of the Kufrah River (Figure 1).

\subsection{The Northern Paleochannels}

We mapped four main northern paleochannels (see Figure 2), which are narrow, single and essentially straight and range from 110 to $190 \mathrm{~km}$-long. They are associated with clear topographic depressions in SRTM data, ranging between 10 and 30 meters in depth, and the corresponding PALSAR images show well defined and narrow (less than $400 \mathrm{~m}$ ) dark channels. The paleochannels all appear to start on a limestone plateau that borders the volcanic relief of $\mathrm{Al}$ Haruj, a young ( $\sim 6$ to $0.5 \mathrm{Ma}$ ) alkaline basaltic intra-continental volcanic field (Ade-Hall et al., 1974). Although we cannot map the paleochannels as far west as the Al Haruj relief because of sand dunes, they are very likely to have originated there. All the paleochannels would have flowed from the southwest to the northeast and appear to terminate about $30 \mathrm{~km}$ to the south of a southerly tributary of the Wadi Sahabi paleochannel, as shown on Figure 3. Although we have no indication about the age of these paleochannels, it is very likely that their formation is related to the Pliocene volcanic events that led to the formation of the Al Haruj relief (Farahat et al., 2006).

\subsection{The Southern Paleochannels}


We mapped three main southern paleochannels, which are also narrow (less than $200 \mathrm{~m}$ ) and essentially straight, but longer (200 to $300 \mathrm{~km}$ ) than the northern ones (see Figure 2).

While they barely present a topographic signature in SRTM data, the PALSAR radar sensor clearly detects them. These paleochannels traverse the Sarir Calanscio plain, which descends northeastwards from the Tibesti mountains (see Figure 2). The three southern paleochannels appear to emerge from the dune fields that cover the Sarir Tibesti: Potentially, they could be extended further southwest towards the Tibesti mountains, but the PALSAR sensor is not able to detect and map them through the thick sand cover. The most southerly paleochannel was previously mapped under the name of Wadi Behar Belama (see Figure 2) by Pachur and Altmann (2006) using LANDSAT-TM images. As with the northernmost paleochannels, the southernmost ones follow a southwest to northeast direction. They terminate at the western margin of the Calanscio Sand Sea, dispersing as networks of small, shallow paleochannels across the surface of alluvial fans (see Figure 4), indicating a decrease in paleoflow competence. Coarse alluvial sand and gravel constituting the fan sediments increase the surface roughness and volume scattering effects, so that the southern paleochannel terminations appear as bright features in the radar images, as shown on Figure 4.

\section{Topography Analysis and Discussion}

The seven paleochannels that we have mapped are consistent with the hypothesis of an extensive Kufrah River paleodrainage system that connected the northern Tibesti mountains to the Sirt Basin during the late Cenozoic as previously proposed by Pachur et al. (Pachur, 1980; Pachur, 1996; Pachur and Hoelzmann, 2000; Pachur and Altmann, 2006). Using LANDSAT-TM imagery, Pachur and colleagues detected remnants of a paleodrainage system formed by the junction of former great wadis originating in the northern Tibesti mountains, that crossed the Sarir Calanscio in a northeast direction. A main representative of this system is Wadi Behar Belama which contains acid volcanic pebbles originating from the Tibesti. Pachur and colleagues also mapped the upper reaches of a paleoriver system sourced in the $\mathrm{Al}$ 
Haruj volcanic relief, that "probably joined drainage systems that flowed into the Mediterranean" (Pachur, 1996), and suggested that this system is likely to have been active

during the early Holocene. The new paleochannels that we have mapped are also consistent with the location of the "humid corridor" proposed by Rohling et al. (2002) and Osborne et al. (2008), that was connecting southeastern Libya to the Mediterranean Sea at around $120 \mathrm{ka}$. Osborne et al. (2008) performed a $\mathrm{Nd}$ isotopic characterization of Quaternary sediments sampled in Wadi Behar Belama and used the findings to support the interpretation of an uninterrupted sediment transport pathway from the Tibesti mountains to the Mediterranean Sea. The alluvial fans at the termini of Wadi Behar Belama and of the two other southern paleochannels (see Figure 2), might then be transitional features produced during drier periods, when the paleoflow competence decreased and sediment throughput could not be maintained. These paleochannels have certainly contributed to sediment supply of the Calanscio Sand Sea (El Baz et al., 2000; Ghoneim et al., 2012) and so may have also contributed to burial of the through-going "north path" of the main Kufrah River that we hypothesized (Paillou et al., 2009).

While full resolution SRTM topography contains very detailed features, particularly dunes, that preclude detailed mapping of the main paleochannels, one can consider the lowfrequency topographic information in order to better infer paleodrainage directions. Craddock et al. (2010) applied this approach to reconstruct a buried fluvial landscape beneath the Simpson Desert eolian dune field in central Australia: While many dunes screen the main drainage directions in full resolution SRTM data, sampling of the low-frequency topography in the topographic lows between the dunes revealed slope trends that trace remnants of paleodrainages. We applied a similar approach here by low-pass filtering the SRTM data in the frequency domain, after a Fourier transform, and by using interpolation techniques to fill SRTM voids: Figure 5a shows the full resolution SRTM topography with voids filled by interpolation, and Figure 5b shows the low-frequency topography obtained after low-pass filtering. Applying a simple threshold to the low-frequency topography allows to directly map the local depressions, represented as light blue areas in Figure 5c. There is no clear evidence 
of a topographic depression that would extend the alluvial fan terminating the Kufrah River to the northwest: The hypothetical "north path" connecting the Sarir Dalmah to the Wadi Sahabi

paleochannel as indicated on Figure 1 cannot be observed on present-day topography (but still could be buried under the dunes of the Calanscio Sand Sea). However, a local depression (path \#1 in Figure 5c) seems to connect the Kufrah River alluvial fan to a western corridor (path \#2 in Figure 5c). The latter runs from the northern Tibesti, through the Wadi Behar Belama in the Sarir Calanscio, and ends south of the Wadi Sahabi paleochannel (see Figure 5c). This large paleocorridor, 10 to $20 \mathrm{~km}$ wide and about $400 \mathrm{~km}$ long, is close to the terminating path of the lower Sahabi River as proposed by Griffin and Drake (see Figure 1) but again, as stated in the introduction of this study, this cannot be considered as a proof for a continuous river system connecting the Chad basin to the Mediterranean Sea. The observed paleocorricor is more likely to have been fed by the northern Tibesti and Al Haruj reliefs, being an ancient pathway between the paleochannels described in the previous section and the northern Wadi Sahabi paleochannel (see Figure 5c). This paleocorridor, as a depression adjacent to the margins of the aggraded Sarir Dalmah alluvial fan, was possibly re-enforced by local tectonics, since its orientation is comparable to the orientation of the main faults in this area (Ahlbrandt, 2001). In particular, one can observe in Figure 3 that the course of two of the northernmost paleochannels shows a change in the paleoflow direction of about $90^{\circ}$ when approaching the paleocorridor from the southwest, suggesting a possible tectonic control by the horst and graben structures in the region (Ahlbrandt, 2001).

The newly mapped paleochannels and the analysis of the local topography thus strongly support the hypotheses proposed by Pachur (1980, 1996), Rohling et al. (2002) and Osborne et al. (2008) of formerly continuous connections between drainage basins in northern Tibesti and the Mediterranean Sea through the Wadi Sahabi paleochannel. Our findings also support our previous hypothesis that the Sarir Dalmah alluvial fan, located at the terminus of the upper part of the Kufrah River system, could have connected to the Wadi Sahabi paleochannel in the north (Paillou et al., 2009). This connection is however not yet obvious, and the Kufrah River is also likely to have terminated as in inland delta in the Sarir Dalmah 
(Paillou et al., 2009), possibly feeding the northern Al Jaghbub paleolake as proposed by Ghoneim et al. (2012). This re-emphasizes the importance of undertaking some exploratory

field work in the Calanscio Sand Sea, using geophysical prospecting techniques such as Ground Penetrating Radar, to detect and map possible paleochannels buried under the sand dunes. The Calanscio Sand Sea is a key area for understanding the history of paleodrainage systems of eastern Libya, and near surface geophysical prospecting could provide new data to help answer outstanding questions regarding the connection of the paleochannels in this area. Exploratory field work is also needed in order to collect samples for geochronological and geochemical analyses that would help determine the ages and histories of the various paleochannels that we have mapped so far: The many tributaries of the Kufrah River system may not necessarily have the same antiquity, some of them possibly being younger impositions on an older paleodrainage network (in particular, the northern paleochannels related to the young volcanic relief of Al Haruj are certainly more recent than the southern ones).

With the plausible assumption that all the seven newly mapped paleochannels at one time were forming part of the Kufrah River paleodrainage system, we can now define a major paleodrainage system in eastern Libya, which at its maximum extent would have drained an area of more than $400000 \mathrm{~km}^{2}$ between the Tibesti, Al Haruj and Gilf Kebir massifs and probably connected to the Mediterranean Sea through the Wadi Sahabi paleochannel in the Sirt Basin. The whole system is likely to have been active at intervals during the late Cenozoic, possibly discharging at that time a comparable amount of water as does the present-day Nile into the Mediterranean Sea. The Kufrah River system is then clearly a major paleohydrological feature to take into account when studying the past environments and climates of northern Africa from the middle Miocene to the Holocene. It also represents a likely corridor for fauna and human dispersal in the eastern Sahara, and thus indicates locations where further paleontological, paleo-anthropological and archeological field exploration should be conducted. 


\section{Acknowledgments}

The authors would like to thank JAXA (Japan Aerospace Exploration Agency) for providing PALSAR data in the framework of the Kyoto \& Carbon Initiative. We also thank P. deMenocal, E. Rohling, J. Maley, Ph. Duringer, Gh. de Marsily and three anonymous reviewers for their very constructive comments on earlier versions of this manuscript. This work was financially supported by the French space agency CNES (Centre National d'Etudes Spatiales).

\section{References}

Abdelsalam M. G. and R. J. Stern, "Mapping precambrian structures in the Sahara Desert with SIRC/X-SAR radar: The neoproterozoic Keraf suture, NE Sudan,” J. Geophys. Res., vol. 101, no. E10, pp. 23063-23076, 1996.

Ade-Hall F. M., P. H. Reynolds, P. Dagley, A. G. Musset, T. B. Hubbard, E. Klitzsch, “Geophysical studies of North African Cenozoic volcanic areas A1-Haruj Assuad, Libya," Canadian Journal of Earth Science, vol. 11, pp. 998-1006, 1974.

Ahlbrandt T. S., "The Sirte Basin province of Libya - Sirte-Zelten Total Petroleum system", U.S. Geological Survey Bulletin 2202-F, 29 p., 2001.

Baghdadi N., G. Grandjean, D. Lahondère, Ph. Paillou, Y. Lasne, "Apport de l'imagerie satellitaire radar pour l'exploration géologique en zone aride," C.R. Geoscience, vol. 337, pp. 719-728, 2005.

Barr F. T. and B. R. Walker, "Late Tertiary channel system in northern Libya and its implications on Mediterranean sea level changes,” In: W. B. F. Ryan et al.. (Eds.), Init. Rep. DSDP 13, pp. 1244$1251,1973$.

Craddock R. A., M. F. Hutchinson, J. A. Stein, “Topographic data reveal a buried fluvial landscape in the Simpson Desert, Australia," Australian Journal of Earth Sciences, vol. 57, pp. 163-171, 2010.

Drake N. A., A. S. El-Hawat, P. Turner, S. J. Armitage, M. J. Salem, K. H. White, S. McLaren, "Palaeohydrology of the Fazzan Basin and surrounding regions: The last 7 million years," Palaeogeography, Palaeoclimatology, Palaeoecology, vol. 263, pp. 131-145, 2008. 
El Baz F., Mainguet M., Robinson C., "Fluvio-aeolian dynamics in the north-eastern Sahara: The relationship between fluvial/aeolian systems and ground water concentration," J. of Arid Environments, vol. 44, pp. 173-183, 2000.

Farahat E. S., M. S. Abdel Ghani, A. S. Aboazom, A. M. H. Asran, "Mineral chemistry of Al Haruj low-volcanicity rift basalts, Libya: Implications for petrogenetic and geotectonic evolution," Journal of African Earth Sciences, vol. 45, pp. 198-212, 2006.

Farr T. G. et al., "The Shuttle Radar Topography Mission,” Rev. Geophys, vol. 45, RG2004, doi:10.1029/2005RG000183, 2007.

Ghoneim E., M. Benedetti, F. El Baz, “An integrated remote sensing and GIS analysis of the Kufrah Paleoriver, Eastern Sahara," Geomorphology, vol. 139-140, pp. 242-247, 2012.

Grandjean G., Ph. Paillou, N. Bahgdadi, E. Heggy, T. August, Y. Lasne, "Surface and subsurface structures mapping using low frequency radar: A synthesis of the Mauritanian and Egyptian experiments," Journal of African Earth Sciences, vol. 44, no. 2, pp. 220-228, 2006.

Griffin D. L., "Aridity and humidity: two aspects of the late Miocene climate of North Africa and the Mediterranean," Palaeogeography, Palaeoclimatology, Palaeoecology, vol. 182, pp. 65-91, 2002.

Griffin D. L., "The late Neogene Sahabi rivers of the Sahara and their climatic and environmental implications for the Chad basin," Journal of the Geological Society, London, vol. 163, pp. 905921, 2006.

Griffin D. L., "The late Neogene Sahabi rivers of the Sahara and the hamadas of the eastern LibyaChad border area," Palaeogeography, Palaeoclimatology, Palaeoecology, vol. 309, pp. 176-185, 2011.

Hallet D., Petroleum Geology of Libya, Elsevier, Amsterdam, 503p., 2002.

Leblanc M., G. Favreau, J. Maley, et al., "Reconstruction of Megalake Chad using Shuttle Radar Topographic Mission data," Palaeogeography, Palaeoclimatology, Palaeoecology, vol. 239, pp. 16-27, 2006.

Lehner B., K. Verdin, A. Jarvis, "New global hydrography derived from spaceborne elevation data," EOS Trans., AGU, vol. 89, no. 10, pp. 93-94, 2008. http://hydrosheds.cr.usgs.gov

Maley J., "Le bassin du Tchad au Quaternaire récent: formations sédimentaires, paléoenvironnements et préhistoire. La question des Paléotchads," In L'évolution de la Végétation depuis deux millions d'années, J. Renault-Miskovsky and A.M. Semah (Eds.), Artcom - Errance, Paris, pp. 179- 217, 2004. 
Maley J., "Climate and palaeoenvironment evolution in north tropical Africa from the end of the Tertiary to the Upper Quaternary,” Palaeoecology of Africa, vol. 30, pp. 227-278, 2010.

McCauley J. F., G. G. Schaber, C. S. Breed, M. J. Grolier, C. V. Haynes, B. Issawi, C. Elachi, R. Blom., "Subsurface valleys and geoarchaeology of the eastern Sahara revealed by Shuttle Radar," Science, vol. 218, pp. 1004-1020, 1982.

Osborne A. H, D. Vance, E. J. Rohling, N. Barton, M. Rogerson, N. Fello, “A humid corridor across the Sahara for the migration of early modern humans out of Africa 120,000 years ago," Proc. Nat. Acad. Sci., vol. 105, pp. 16444-16447, 2008.

Pachur H. J., "Climatic history in the Late Quaternary in southern Libya and the western Libyan desert,” In: M. J. Salem and M. T. Busrewil (Eds.), The Geology of Libya, vol. 3, Academic Press, London, pp. 781-788, 1980.

Pachur H. J., "The Geology of Syrte Basin - vol 1 - Reconstruction of paleodrainage systems in Syrte Basin and the area surrounding the Tibesti Mountains: Implications for the hydrological history of the region," First symposium on the sedimentary basins of Libya, Tripoli, Elvesier Eds., 1996.

Pachur H. J. and P. Hoelzmann, "Late Quaternary palaeoecology and palaeoclimates of the eastern Sahara," Journal of African Earth Sciences, vol. 30, pp. 929-939, 2000.

Pachur H. J. and N. Altmann, Die Ostsahara im Spätquartär, Springer Berlin Heidelberg New York, 662 p., 2006.

Paillou Ph., G. Grandjean, N. Baghdadi, E. Heggy, Th. August-Bernex, J. Achache, "Sub-surface imaging in central-southern Egypt using low frequency radar: Bir Safsaf revisited," IEEE Transactions on Geoscience and Remote Sensing, vol. 41, no. 7, pp. 1672-1684, 2003.

Paillou Ph., A. Rosenqvist, J.-M. Malézieux, B. Reynard, T. Farr, E. Heggy, "Discovery of a double impact crater in Libya: the astrobleme of Arkenu," C.R. Geoscience, vol. 335, pp. 1059-1069, 2003.

Paillou Ph., A. El Barkooky, A. Barakat, J.-M. Malézieux, B. Reynard, J. Dejax, E. Heggy, "Discovery of the largest crater field on Earth in the Gilf Kebir region, Egypt," C.R. Geoscience, vol. 336, pp. 1491-1500, 2004.

Paillou Ph., Y. Lasne, E. Heggy, J.-M. Malézieux, "A study of P-band SAR applicability and performance for Mars exploration: Imaging subsurface geology and detecting shallow moisture," Journal of Geophysical Research, vol. 111, E06S11, 2006. 
Paillou Ph., B. Reynard, J.-M. Malézieux, J. Dejax, E. Heggy, P. Rochette, W. U. Reimold, P. Michel, D. Baratoux, Ph. Razin, J.-P. Colin, "An extended field of crater-shaped structures in the Gilf

Kebir region - Egypt: Observations and hypotheses about their origin," Journal of African Earth Sciences, vol. 46, pp. 281-299, 2006.

Paillou Ph., M. Schuster, S. Tooth, T. Farr, A. Rosenqvist, S. Lopez, J.-M. Malézieux, "Mapping of a major paleodrainage system in Eastern Libya using orbital imaging Radar: The Kufrah River," Earth and Planetary Science Letters, vol. 277, pp. 327-333, doi: 10.1016/j.eps1.2008.10.029, 2009.

Paillou Ph., S. Lopez, T. Farr, A. Rosenqvist, "Mapping Subsurface Geology in Sahara using L-band SAR: First Results from the ALOS/PALSAR Imaging Radar," IEEE J. of Selected Topics in Earth Observations and Remote Sensing, vol. 3, no 4, pp. 632-636, 2010.

Petit-Maire N., "Climatic change and cultural change in the Sahara over the last 130 ka," In: Il sistema Uomo-Ambiente tra passato e presente, Albore Livadie C., Ortolani F. Eds., Centro universitario europeo per i beni culturali, pp. 311-316, 1998.

Robinson C. A., F. El-Baz, T. S. M. Al-Saud, S. B. Jeon, "Use of radar data to delineate palaeodrainage leading to the Kufra oasis in the eastern Sahara," Journal of African Earth Sciences, vol. 44, pp. 229-240, 2006.

Rohling E. J., T. R. Cane, S. Cooke, M. Sprovieri, I. Bouloubassi, K. C. Emeis, R. Schiebel, D. Kroon, F. J. Jorissen, A. Lorre, A. E. S. Kemp, "African monsoon variability during the previous interglacial maximum,” Earth and Planetary Science Letters, vol. 202, pp. 61-75, 2002.

Rosenqvist A., M. Shimada, N. Ito, M. Watanabe, “ALOS PALSAR: A pathfinder mission for globalscale monitoring of the environment," IEEE Transactions on Geoscience and Remote Sensing, vol. 45, no. 11, pp. 3307-3316, 2007.

Schaber G. G., J. F. McCauley, C. S. Breed, and G. R. Olhoeft, "Shuttle Imaging Radar: Physical controls on signal penetration and subsurface scattering in the Eastern Sahara," IEEE Transactions on Geoscience and Remote Sensing, vol. GE-24, no. 4, pp. 603-623, 1986.

Schuster M., Ph. Duringer, J.F. Ghienne, et al., "Chad Basin: Paleoenvironments of the Sahara since the Late Miocene," C.R. Geoscience, vol. 341, pp. 603-611, 2009.

Swezey C. S., "Cenozoic stratigraphy of the Sahara, Northern Africa," Journal of African Earth Sciences, vol. 53, pp. 89-121, 2009. 


\section{Figure Captions}

Figure 1: The Kufrah River paleodrainage system and the Wadi Sahabi paleochannel (in blue) mapped onto a LANDSAT-TM mosaic. The hypothetical "north path" proposed by Paillou et al. (2009) and "Sahabi River" proposed by Griffin (2002) and Drake (2008) are indicated as dashed red lines.

Figure 2: The seven paleochannels, four northern ones and three southern ones - including Wadi Behar Belama - which have been mapped using SRTM and PALSAR data. Background is SRTM topography with interpolation to fill voids.

Figure 3: Northern limit of the northernmost paleochannels (thin blue) which are likely to have connected to a southern tributary of the Wadi Sahabi paleochannel (thick blue), located $30 \mathrm{~km}$ to the north. Background is interpolated SRTM topography.

Figure 4: PALSAR image of the northern limit of the southern paleochannels. They terminate at the western margin of the dunes of the Calanscio Sand Sea, dispersing as a network of small, shallow paleochannels across the surface of radar-bright alluvial fans.

Figure 5: a. The Kufrah River, the Wadi Sahabi paleochannel and the seven newly mapped paleochannels on top of the full resolution SRTM topography. b. The same features shown over the low-frequency topography obtained after filtering in the Fourier domain. c. Local depressions (light blue areas) extracted from the low-frequency topography. "Path \#1" shows a narrow valley which could connect the Sarir Dalmah alluvial fan to a paleocorridor "Path \#2". This paleocorridor, 10 to $20 \mathrm{~km}$ wide and about $400 \mathrm{~km}$ long, runs from the northern Tibesti, through the Wadi Behar Belama in the Sarir Calanscio, and ends south of the Wadi Sahabi paleochannel. 


\section{Légende des figures}

Figure 1 : Le système paléo-hydrographique de la rivière de Kufrah et le paléochenal Wadi Sahabi (en bleu) sur fond de mosaïque LANDSAT-TM. Le "north path" hypothétique proposé par Paillou et al. (2009) et la "Sahabi River" proposée par Griffin (2002) et Drake (2008) sont indiqués en traits pointillés rouges.

Figure 2 : Les sept paléochenaux, quatre septentrionaux et trois méridionaux - incluant le Wadi Behar Belama - qui ont été cartographiés à partir des données SRTM et PALSAR. Le fond est la topographie SRTM, interpolée pour combler les trous.

Figure 3 : Limite nord des paléochenaux septentrionaux (tracé bleu fin) qui semblent se connecter à un affluent méridional du paléochenal Wadi Sahabi (tracé bleu épais), localisé 30 km plus au nord. Le fond est la topographie SRTM interpolée.

Figure 4 : Image PALSAR de la limite nord des paléochenaux méridionaux. Ils se terminent à la bordure occidentale des dunes de la mer de sable de Calanscio, se dispersant en un réseau de petits chenaux, présentant une signature radar brillante, à la surface de cônes alluviaux.

Figure 5 : a. La rivière de Kufrah, le paléochenal Wadi Sahabi et les sept nouveaux paléochenaux sur fond de topographie SRTM. b. Les mêmes structures superposées à la composante basse fréquence de la topographie, obtenue par filtrage dans le domaine de Fourier. c. Dépressions locales (zones en bleu clair) extraites de la topographie basse fréquence. Le "path \#1" indique une vallée étroite qui connecte potentiellement le cône alluvial du Sarir Dalmah à un paléocorridor "path \#2”. Ce paléocorridor, large de 10 à $20 \mathrm{~km}$ et long d'environ $400 \mathrm{~km}$, débute dans la région nord du Tibesti, suit le Wadi Behar Belama dans le Sarir Calanscio, et se termine au sud du paléochenal Wadi Sahabi. 


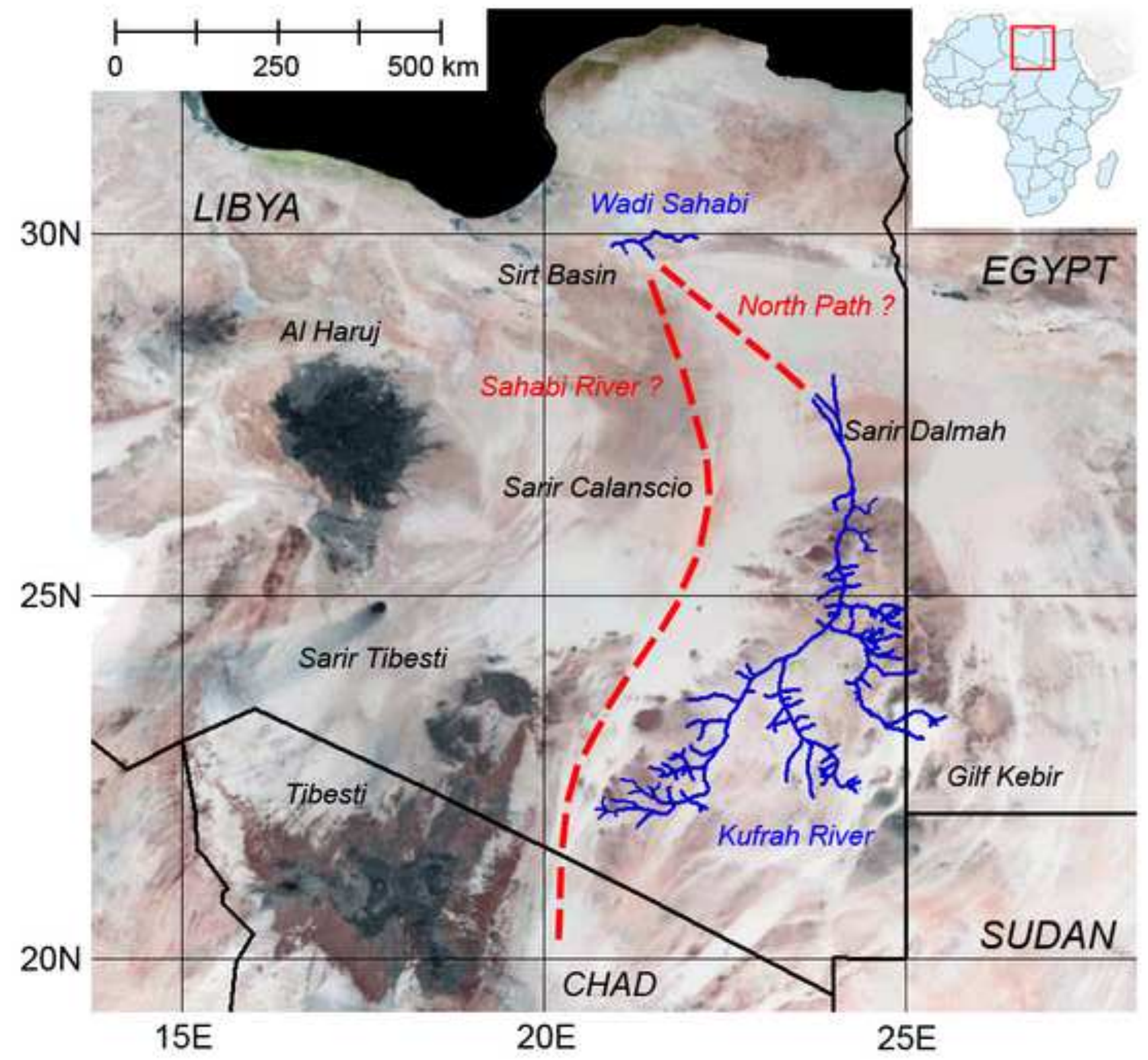


Figure (pas au format Adobe Illustrator / Not Adobe Illustrator file)

Click here to download high resolution image

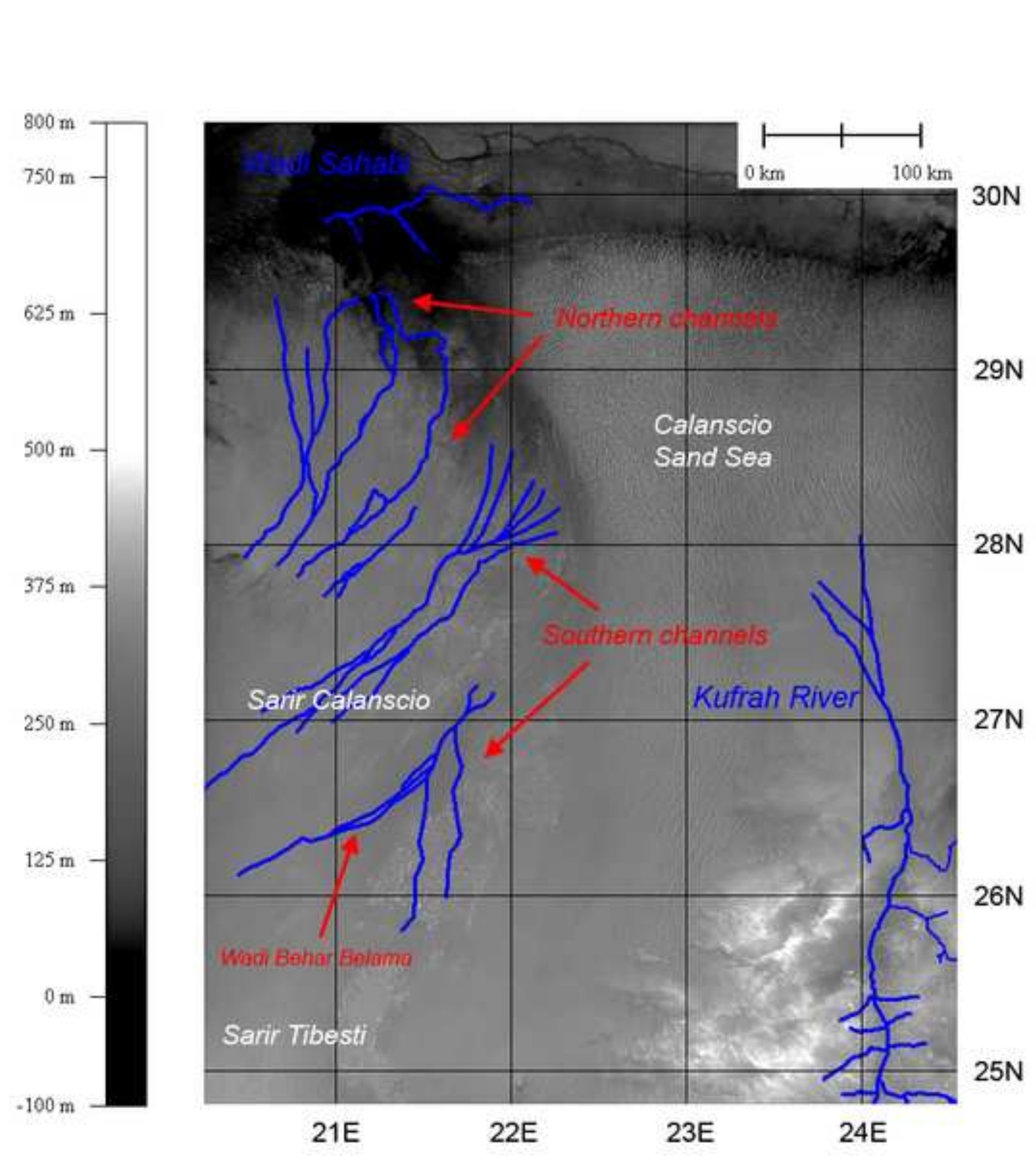

\author{
(e)
}

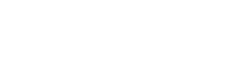

$$
\text { (litustrator file) }
$$

igh resolution image 
Figure (pas au format Adobe Illustrator / Not Adobe Illustrator file)

Click here to download high resolution image

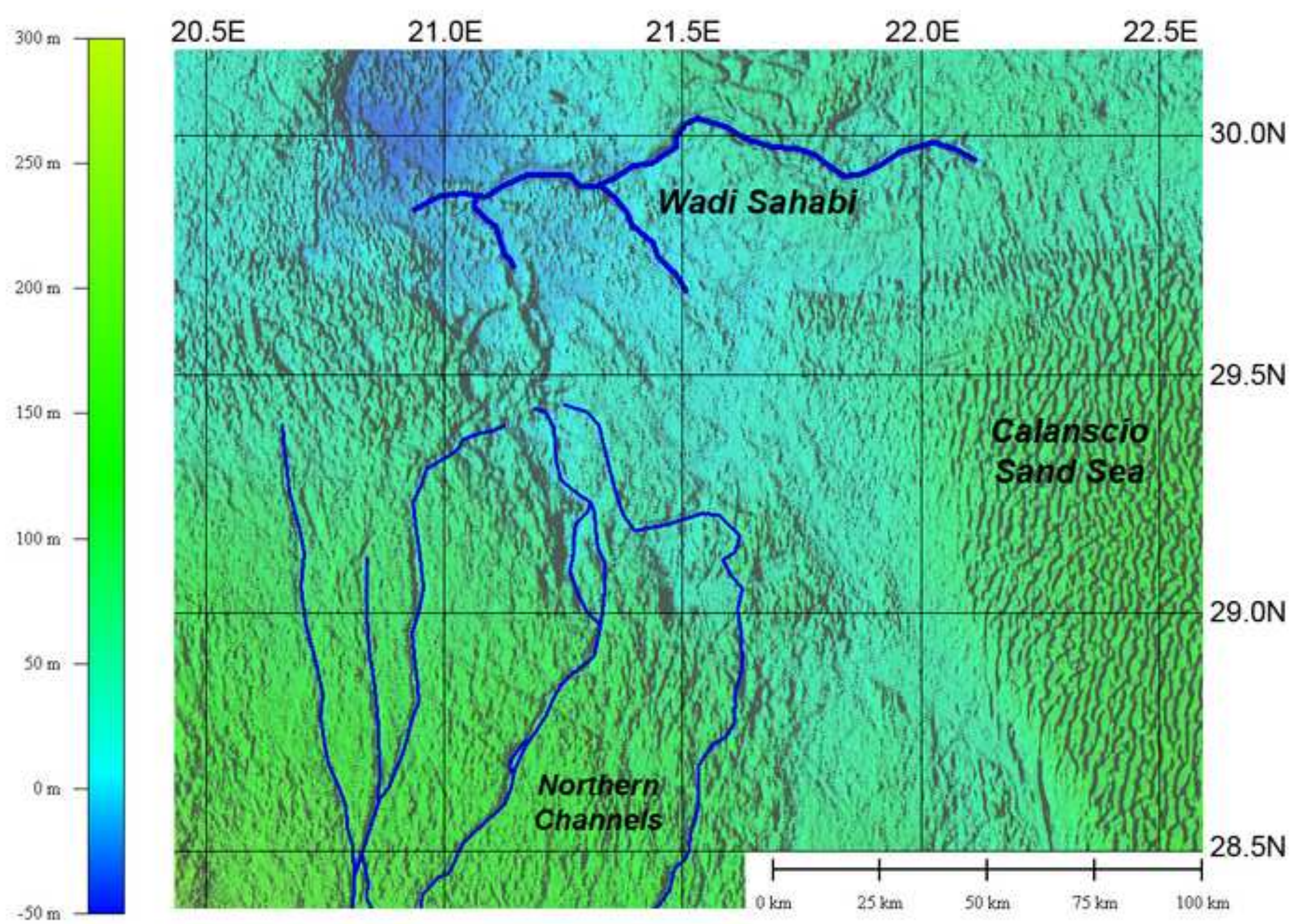




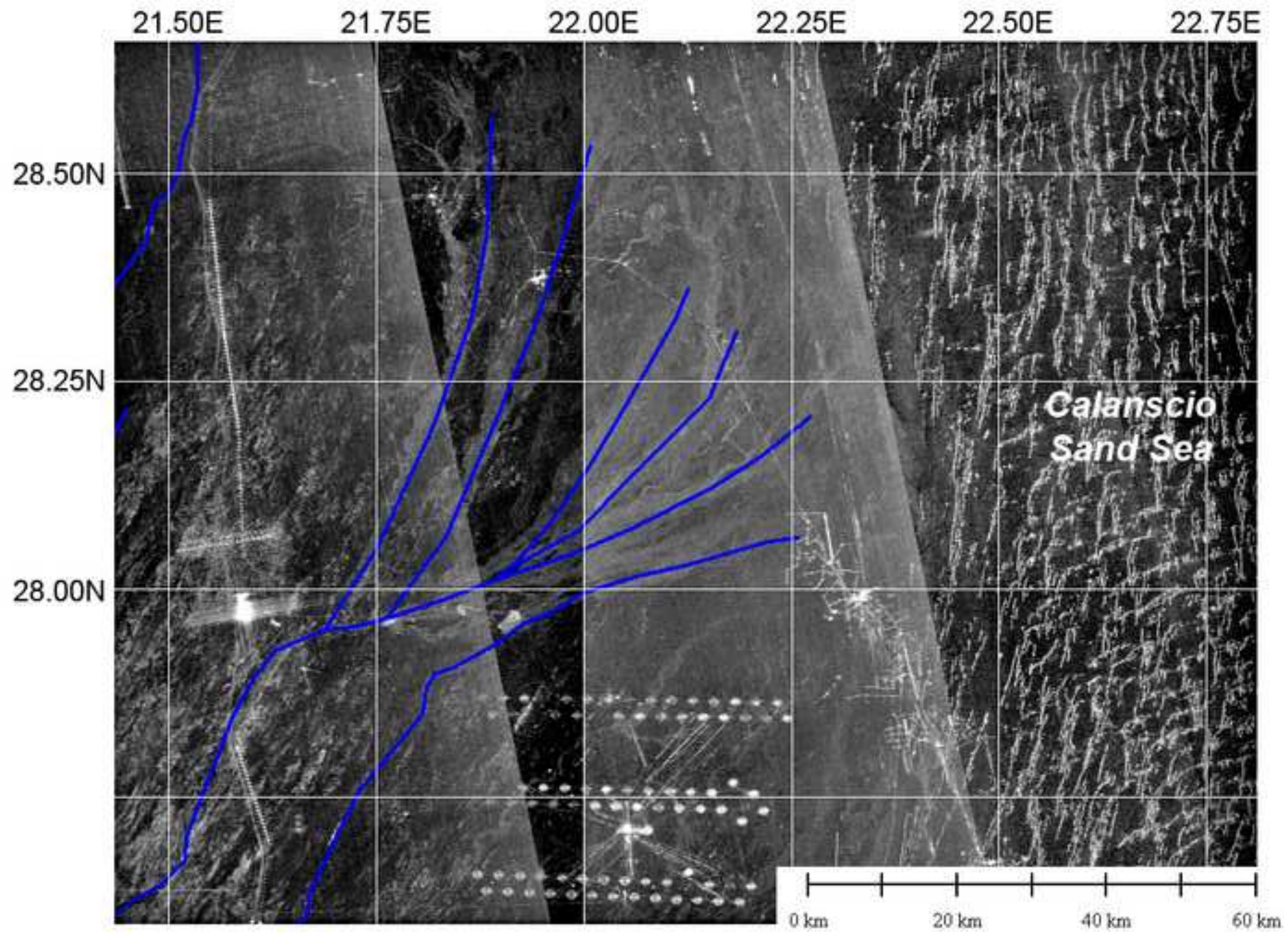



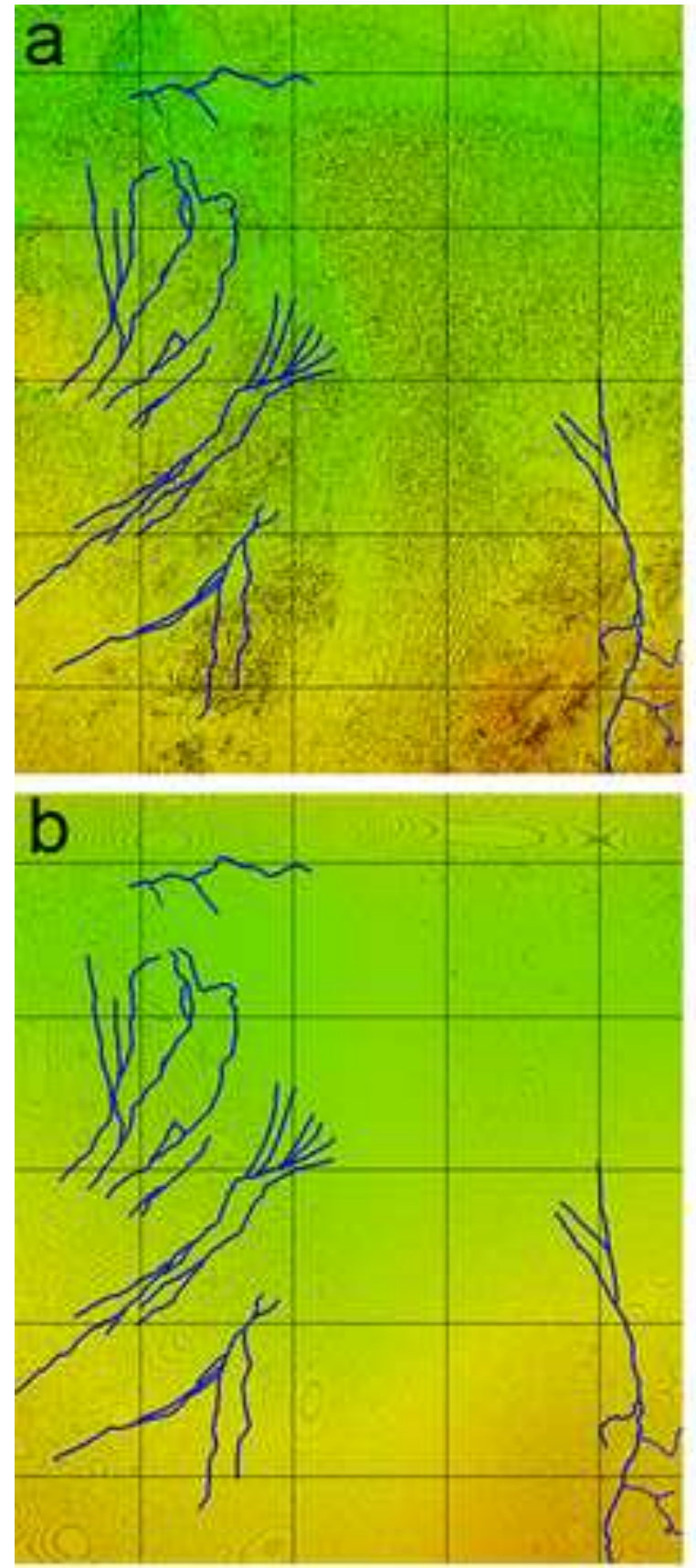

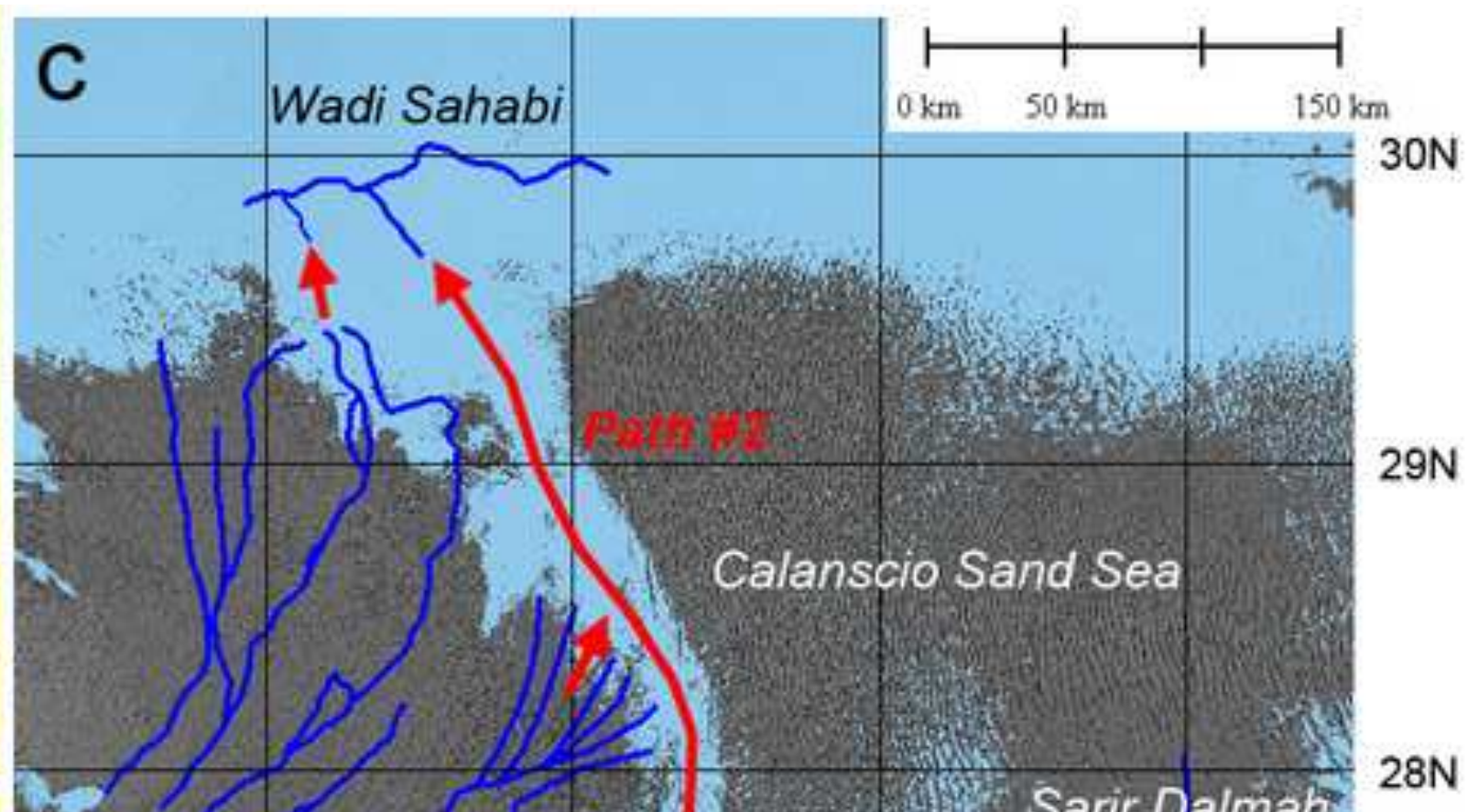

Western Paleochannels

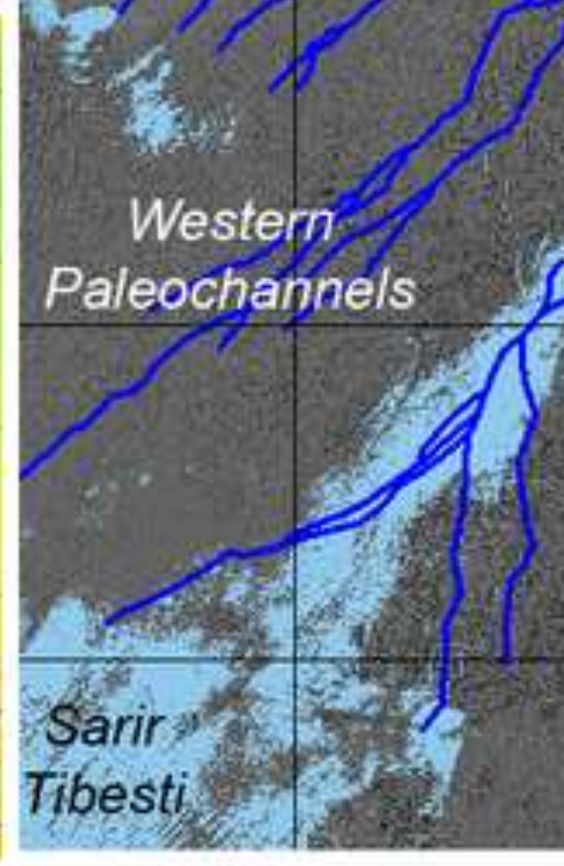

$21 \mathrm{E}$
$22 \mathrm{E}$
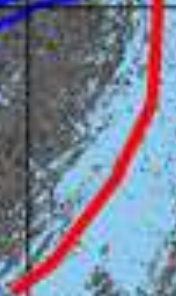

Sarir Dalmaht

$28 \mathrm{~N}$

$27 N$

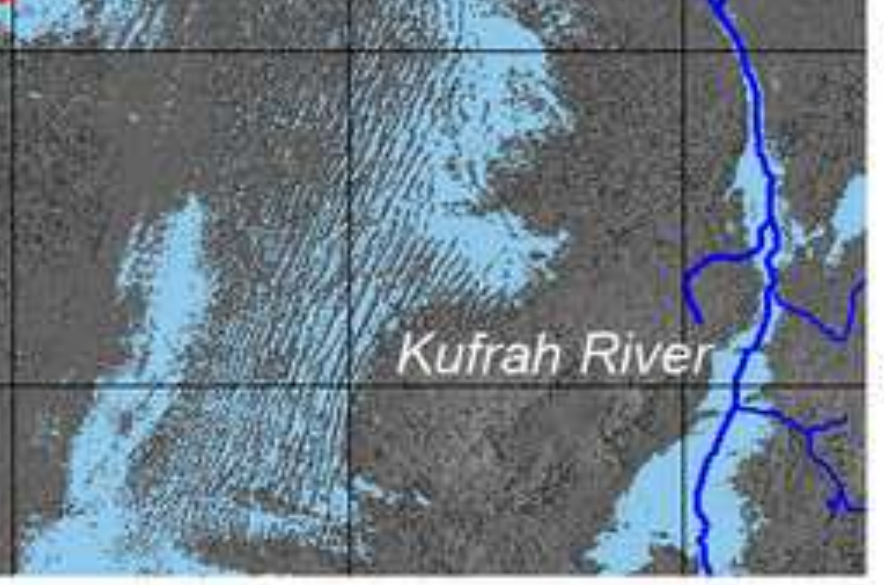

$23 E$ 